\title{
LOWER CRETTACEOUS SEDIMENTARY SEQUENCES IN THE BASIN, NORTHEASTERN BRAZIL: A REVISION
}

\author{
MARIA AUGUSTA MARTINS DA SILVA*
}

\begin{abstract}
The Araripe Basin in northeastern Brazil contain a $700 \mathrm{~m}$-thick succession of Jurassic-Cretaceous strata. The $200 \mathrm{~m}$-thick Lower Cretaceous is widely known for its fish-bearing concretions and gypsum deposits. Detailed field studies and core analyses provided data for revision of the Lower Cretaceous stratigraphy in the Araripe Basin. A regional disconformity within the Lower Cretaceous succession is described here for the first time. This surface divides the Aptian-Albian succession into two parts: 1. a lower sequence of black shale, laminated carbonate, algal mat carbonates, and evaporites in ascending stratigraphic order; and 2 . an overlying sequence containing concretionary shale, limestone, and sandstone. These two stratigraphic divisions are herein defined as the Araripina Formation (new name) and the Santana Formation (revised), respectively. The expression of the disconformity varies across the basin. In the southwest it is marked by caves formed in the gypsum and a karstic topography. Towards the northeast, a $50 \mathrm{~cm}$-thick layer of laminar calcareous and siliceous calcrete crust marks the disconformity surface.
\end{abstract}

RESUMO A Bacia do Araripe no nordeste do Brasil apresenta uma sucessão sedimentar de idade jurássico-cretácica de aproximadamente $700 \mathrm{~m}$ de espessura. As rochas do Cretáceo Inferior, com cerca de $200 \mathrm{~m}$ de espessura, são bem conhecidas pelos depósitos de gipsita e concreções contendo peixes. Este artigo apresenta uma revisão da estratigrafia do Cretáceo Inferior com base em trabalho de campo e análise de testemunhos. Verificou-se a existência de uma discordância regional truncando as rochas do Cretáceo Inferior. Esta superfície erosiva divide o pacote Aptiano-Albiano em duas partes: 1. uma seqüência inferior de folhelhos pretos, carbonatos laminados e carbonatos com esteiras algálicas, e evaporitos no topo da seqüência; e 2. uma seqüência superior contendo folhelho rico em concreções, calcário e arenito intercalado. Essas duas seqüências sedimentares são aqui formalmente definidas e nomeadas de, respectivamente, Formação Araripina (nome novo) e Formação Santana (revisada). A superfície de discordância se apresenta basicamente de duas formas distintas. Na parte sudoeste da bacia, ela aparece como cavernas e depressões na rocha formada por gipsita definindo uma paleotopografia kárstica. Na parte nordeste, ela ocorre como uma superfície de cerca de $50 \mathrm{~cm}$ de espessura formada por crostas laminares de calcário e sílica (calcrete).

INTRODUCTION The Araripe Basin is located in northeastern Brazil about $400 \mathrm{~km}$ northwest of Recife (Fig. 1). This Mesozoic basin contains a sequence of sedimentary rocks surrounded and underlain by rocks of the Brazilian Shield (Fig. 2). Late Cretaceous-Early Tertiary uplift formed a conspicuous plateau of Mesozoic sedimentary rocks, the Araripe Plateau elevated 600-900 m above sea level and extending $200 \mathrm{~km}$ in an eastwest direction and $70 \mathrm{~km}$ (maximum value) north to south. The Araripe Basin first formed in the Jurassic associated with rifting during initial breakup of South America and Africa. This rifting produced a series of graben-like basins along and west of the present Brasilian Margin which were initially filled with Jurassic fluvial and lacustrine deposits. Widening, inundation and later evaporation of this basin in the Early Cretaceous resulted in deposition of lacustrine evaporites and interbedded shales and limestones. Mesozoic sedimentation ended in the Albian and is marked by a fluvial sandstone (Exu Formation) which now cap the Araripe Plateau (Fig. 2).

The Lower Cretaceous formations, that is the Santana and Araripina Formations, respectively, the subjects of this work, are well known for the abundant and well preserved fossil fish found in concretions in shale, and for gypsum deposits (Oliveira et al. 1979, Scheid et al. 1978, Moraes et al. 1975, Munis 1971, Mabesoone 1971, Silva Santos \& Valença 1968, Braun 1966, Beurlen 1963, Jordan 1923, Small 1913).

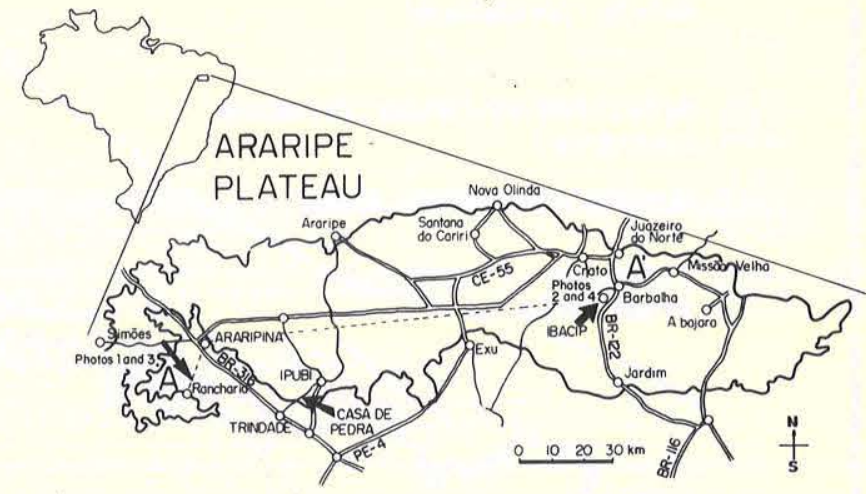

Figure 1 - Location of the Araripe Plateau in the northeastern interior of Brazil. AA' line represents section shown in figure 6 (Modified from DNPM 1974a)

Much controversy surrounds the stratigraphy of the Araripe Basin; the systems proposed in the past have been mainly based on paleontological studies of fish and ostracod assemblages (Figs. 3 and 4). Some additional stratigraphic information resulted from field work and sulfide prospecting. The formations and members defined for the Cretaceous succession have been constantly modified (Figs. 3 and 4) and a stable and comprehensive system of nomenclature based on carefully defined stratigraphic units 
is necessary before the paleoenvironments and evolution of the Araripe Basin can be interpreted. The purpose of this paper is to clarify the stratigraphy of the Cretaceous rocks of the Araripe Basin. The work is based on field observations carried on during July, 1981, and on the study of cores drilled by the brazilian Departamento Nacional da Produção Mineral (DNPM) and by the Superintendência de Desenvolvimento do Nordeste (Sudene). Interpretation of the depositional environments and evolution of the Araripe Basin was presented by Silva (1983) and will not be here discussed.

PREVIOUS WORK The first published account on the stratigraphy of the Araripe Basin was by Small (1913), who named a sequence of interbedded limestone and marl containing two fluvial deposits the Sant'Ana Limestones. At present, paleontologists and stratigraphers who have worked on that area disagree on the definition of the Santana Formation (Fig. 3), as follows:

Beurlen (1962) defined the Santana Formation as a series of bituminous shales, laminated limestones, gypsite, clayey siltites, and marls with calcareous concretions divided into three informal members: 1. a lower member consisting of interbedded shale and laminated limestone; 2. a middle member represented by gypsite; and 3 . an upper member including marl, siltite, and limestone (Fig. 3). In 1963, Beurlen removed the lower limestone member from the Santana Formation and described it as the Crato Formation. He then grouped the middle gypsite member and the upper limestone member together in the Santana Formation (Fig. 3).

Moraes et al. (1963), based on photogeologic interpretation, divided the Santana Formation into two informal members: 1. a lower member composed of shale, laminated limestone, and gypsum; and 2. an upper member composed of concretionary marl, clay, and limestone.

Braun (1966) redefined the Santana Formation as a sequence of siltites, marls, limestones, and dark shale with intercalated layers of gypsum unconformably bounded by the two fluvial deposits (Figs. 3 and 4). Braun (op. cit.) did not recognize members and disagreed with Beurlen's (1963) subdivision of the sequence into two formations, and dated the sedimentary rocks of the Araripe Basin on the basis of rich fossil biotas. He correlated the fresh-water ostracods of the Santana Formation in the Araripe region with those of Aptian age in the coastal basins of Brazil described by Krommelbein (1965), Krommelbein \& Wenger (1966), and Viana (1966), and especially with the assemblage from the well-studied Sergipe Basin.

In 1968, Silva Santos \& Valença conducted a paleontologic and geologic survey in the Araripe Basin in connection with the study of fossil-fish assemblage of the Santana Formation. They disagreed with both Braun's (1966) and Beurlen's (1962) stratigraphic nomenclature of the Santana Formation. Instead, they adopted the stratigraphic terminology of Moraes et al. (1963) (Fig. 3) based on the following arguments: 1. great lithologic and paleontologic similarity between the Crato

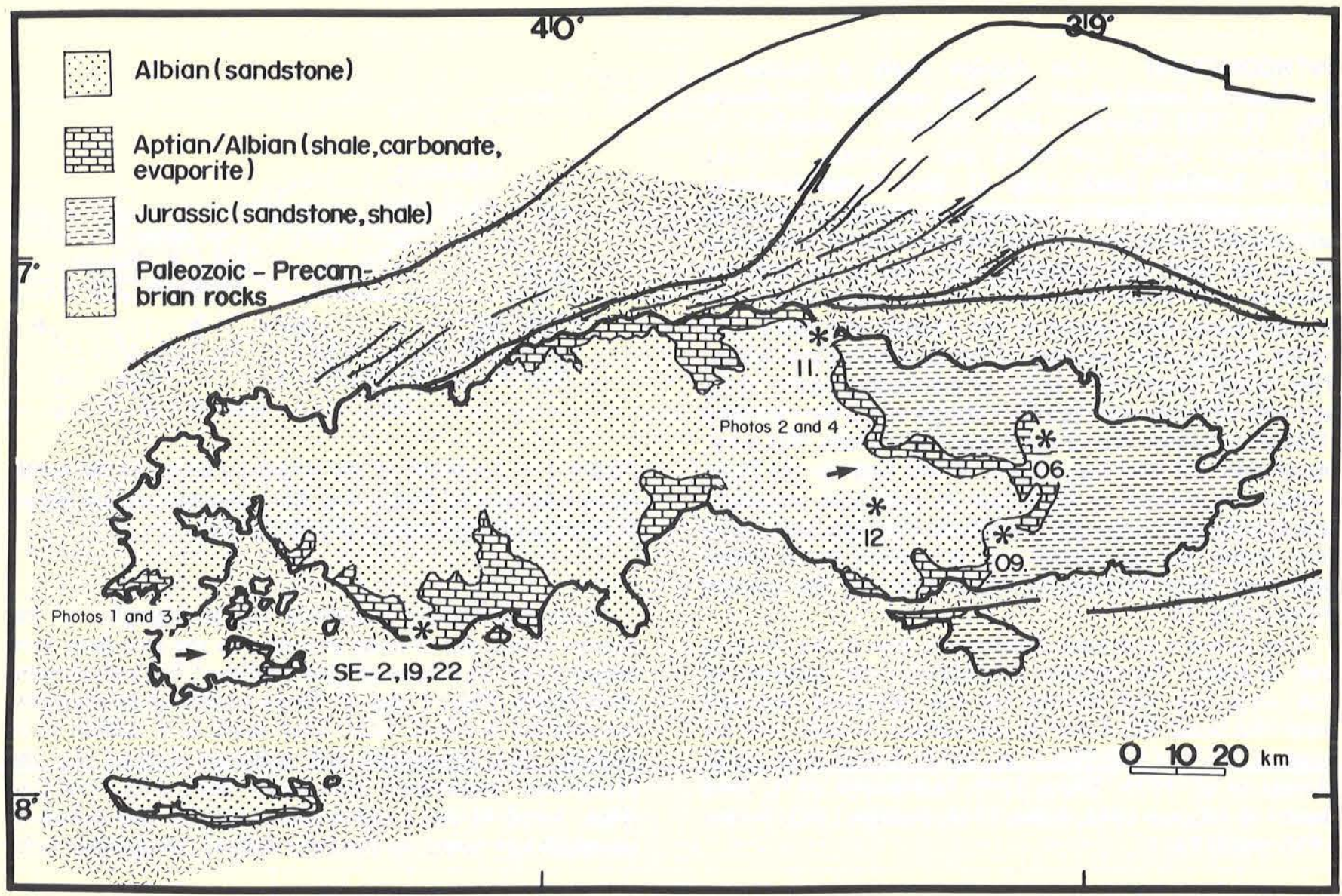

Figure 2 - Geologic map of the Araripe Basin showing locations of cores studied in this work (From DNPM 1974a and b) 


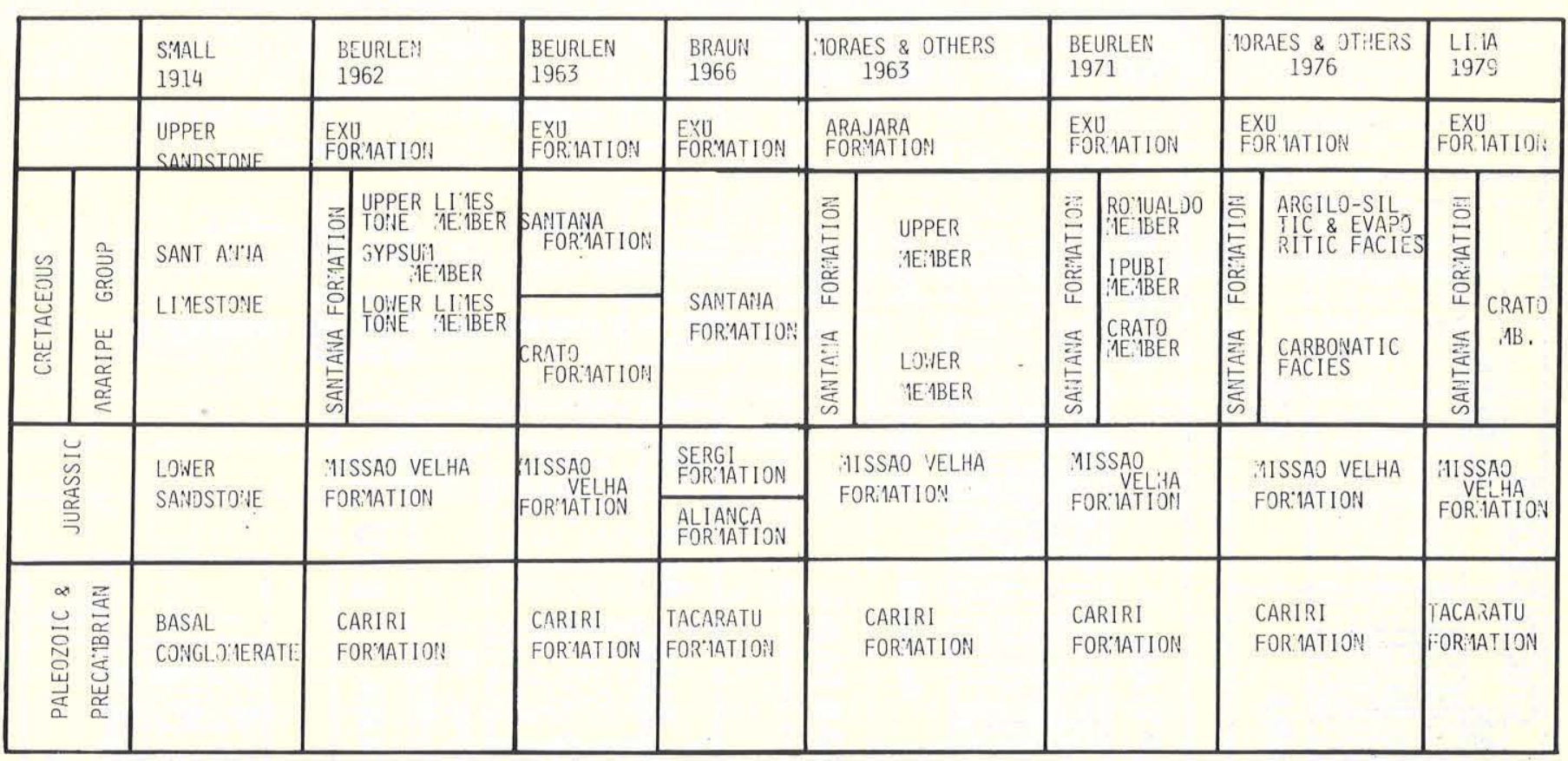

Figure 3 - Table of stratigraphic names used by previous workers for the Lower Cretaceous sedimentary rocks of the Araripe Basin

and Santana Formations which suggests that they should be grouped together in one formation; 2. the gypsum layer represents a normal part of a carbonate to evaporite succession in a normal precipitation of salts from a brine, and lithogenetically should be grouped with the carbonates at the top of the lower member; and 3. the continuity and thickness of the gypsum layer makes it an important stratigraphic horizon which allows easy division of the Santana Formation into two members. Based on the fossil fish assembly in the calcareous concretions of the upper member of the Santana Formation and their correlation with European and African species, Silva Santos \& Valença (1968) assigned a probable Aptian age to the Santana Formation.

Beurlen (1971) reconsidered his previous works (1962, 1963) abandoning the name Crato Formation and redefining the whole sequence as the Santana Formation (Fig. 3). However, he did not follow the divisions of Moraes et al. (1963) or Silva Santos \& Valença (1968). Based on his 1962 work, Beurlen (1971) divided the Santana Formation into three new formal members and argued that each represented a distinct phase of sedimentation during Santana deposition, in ascending stratigraphic order: 1. the lower Crato Member characterized by laminated limestone and siltite; 2 . the middle Ipubi Member comprised of gypsite, limestone, and concretionary marl; and 3 . the upper Romualdo Member containing siltite and argillite. According to Beurlen (op. cit.), the Santana Formation was conformable between the two adjacent fluvial sandstone layers.

In the 1970's, the Araripe Basin was intensely prospected for gypsum, sulfides, and for fossil-fish-bearing concretion localities in order to control their commercial exploration (Moraes et al. 1975, Moraes et al. 1976, Scheid et al. 1978, Oliveira et al. 1979). These workers generally followed Beurlen's (1971) stratigraphic nomenclature, but further adopted a lithofacies division as follows: 1. a carbonate facies considered equivalent to the Crato Member and the lower part of the Ipubi Member; 2. an argillo-siltic and evaporitic facies considered to be equivalent to the upper part of the Ipubi and the Romualdo members.

Lima (1979) pointed out the need to reconsider the subdivisions of the Santana Formation as proposed by Beurlen (1971). Lima believed that only the Crato Member was clearly distinguishable and should be retained; he stated that the Ipubi and Romualdo Members should either be abandoned or redefined because " 1 . they represent a continuous lithologic sequence and do not represent distinct phases in the deposition of the Santana Formation; 2 . they show complex contacts and great faciologic variation" (Fig. 3). Based upon biostratigraphic considerations and field work, Lima (1979) defined the Santana Formation as a cyclic marine-nonmarine sequence of upward fining sandstone, shale, dark shale, and limestone, which in turn is overlain by an upward-coarsening shale, sandstone, and siltite facies sequence to the top of the formation. He considered the gypsum to be a lenticular body in the argillite and siltite layers (Fig. 4).

During field work, the author observed that the stratigraphy of the basin as defined by Moraes et al. (1963) on the basis of photogeology helped to identify the sedimentary sequences. However, the erosional unconformity truncating these sequences precluded them from being defined as members of the Santana Formation (as proposed by Moraes et al. 1963). As it will be shown below there are two defined formations limited by an unconformity.

PRESENT WORK The figure 5 defines the stratigraphic sequences for the Araripe Basin based on the present study. Cretaceous rock-stratigraphic units are herein formally propoded. These are the Araripina Formation and the Santana Formation (revised) separated by the regional unconformity. The Jurassic and Albian nomenclature shown (Fig. 5) is the most widely accepted in the Brazilian 


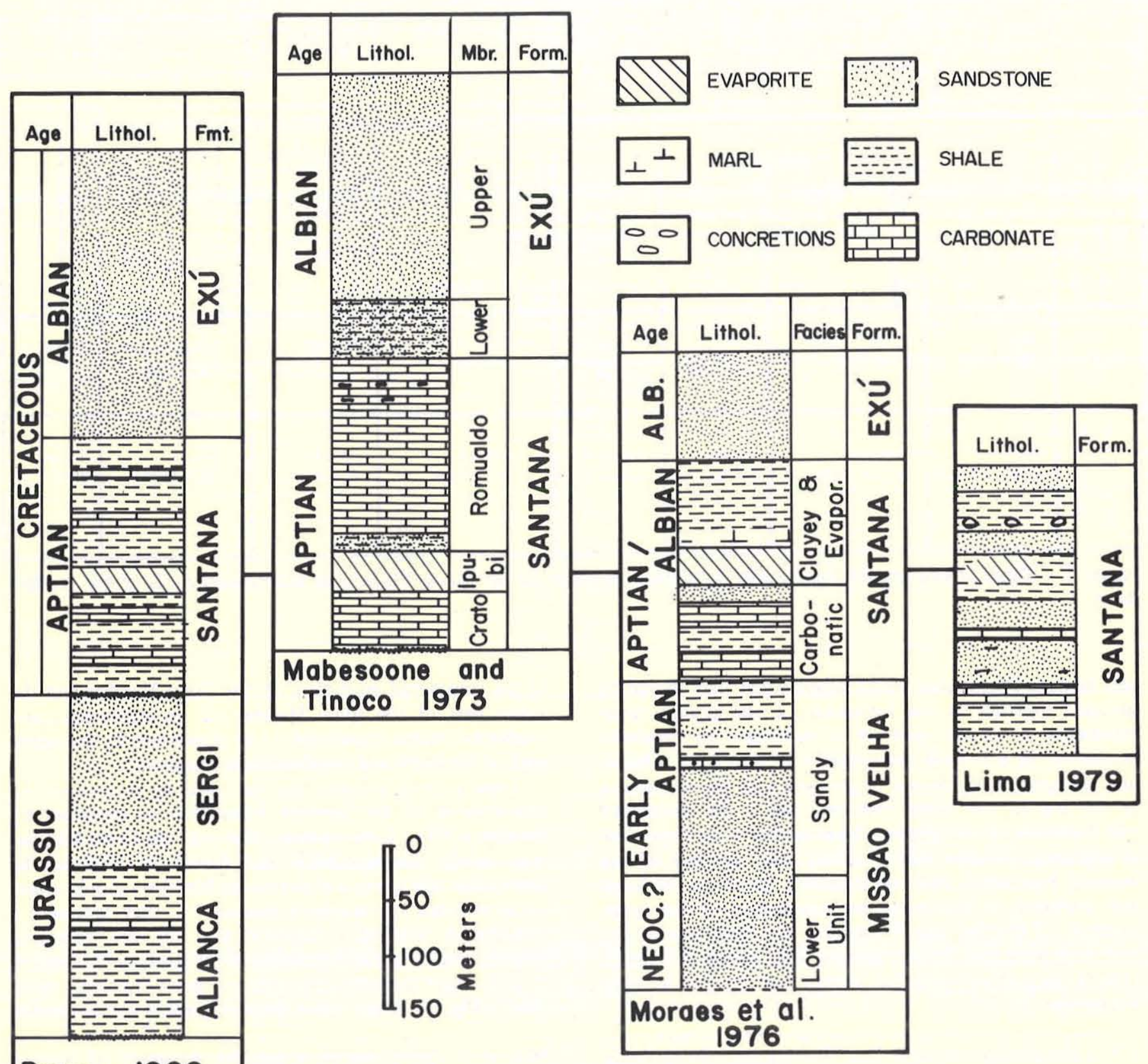

Figure 4 - Columnar sections illustrating lighology and stratigraphic names used by previous workers in the Araripe Basin

literature, and is adopted here. The Aptian sedimentary rocks in question lie unconformably between these two fluvial deposits. The Aptian sequence of black shale at the base passing upwards to limestone, then algal laminated shale, and on top, an evaporite layer is herein defined as the Araripina Formation. This sequence corresponds with the Crato Member and the lower part of the Ipubi Member of Beurlen (1971). The upper unit of the Aptian sequence is represented by alternating layers of concretionary shale and limestone with intertonguing sandstone and is herein redefined as the Santana Formation. This sequence corresponds with the upper part of the Ipubi Member and the Romualdo Member of Beurlen (op. cit.).
An erosional surface was observed on top of the evaporite layer, as evidenced by dissolution features resembling karst topography, a hard calcareous and siliceous-cemented surface (calcrete) and a conglomerate layer present at different localities. This unconformity could be traced regionally in outcrop and quarries and forms a key marker horizon which divides the sedimentary sequence into the two distinct formations described above (Fig. 5).

EVIDENCE FOR UNCONFORMITY The expression of the disconformity surface (Dunbar \& Roger 1957, p. 119) varies across the basin (Fig. 6). To the south, the erosion surface is a paleokarst landscape whereas to the northeast, 
it is a calcrete layer. At the extreme southwest of the area, it is an erosional surface separating Cretaceous rocks from underlying Paleozoic rocks.

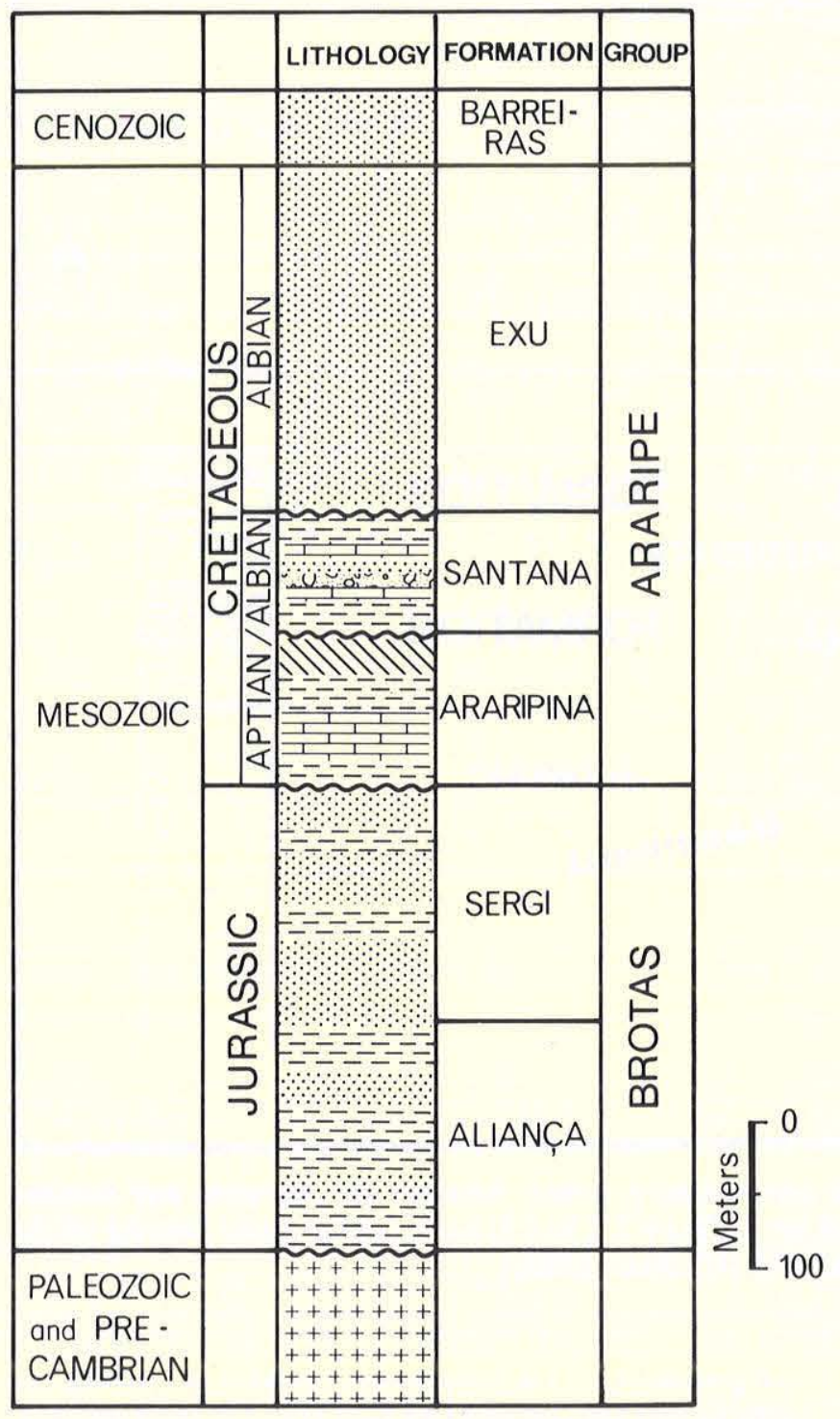

Sandstone

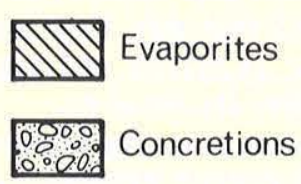

$E=-=-1$ Shale

0.009 Concretions

P卧 Carbonate

Figure 5 - Columnar section and proposed stratigraphic nomenclature for the Lower Cretaceous sedimentary rocks of the Araripe Basin, based on the present study

In the quarries around the Araripina region (Fig. 1), the top of the gypsum layer shows conspicuous dissolution caves (Photo 1A). These caves or sinks, which have been filled in by mud, vary in size but on average they are 1 to $2 \mathrm{~m}$ across and 2 to $3 \mathrm{~m}$ deep. The overlying sedimentary rocks show to signs of dissolution or karst formation. Post-burial solution features (Wright 1982) such as pipes connecting the overlying sedimentary rocks with the paleokarstic surface are not present. Consequently, caves and sinks formed in the gypsum are inferred to have resulted from subaerial dissolution.

In the northeast part of the basin, around Crato and Missão Velha, this paleokarst surface disappears and is replaced by a calcrete layer (Fig. 6), probably due to variations in the moisture distribution in the region (Silva 1983). This layer is best displayed at IBACIP Quarry as $20 \mathrm{~cm}$-thick calcareous and siliceous laminar crusts on top of the algal laminated shale (Photo 1B). Chert nodules, drusy calcite, and slight brecciation were observed along this surface. The results of petrographic work confirm the presence of calcrete-related features and vadose diagenesis (Silva 1983). Overlying the calcrete layer is a $50 \mathrm{~cm}$-thick layer of conglomerate (Photo 1B).

The calcrete layer at IBACIP occurs as a protruding hard surface in the middle part of the exposure (Photo 1B); the beds above and below it are essentially parallel. The recognition of such a surface as a disconformity can be difficult. Detailed observation in the field and/or systematic petrographic and facies analyses revealed a break in sedimentation, and subaerial diagenesis (Silva 1983). The absence of gypsum in IBACIP may also be an indication of an erosional interval before deposition of the upper sediments of the revised Santana Formation, i.e., due to local total dissolution of gypsum during development of karst topography.

In the Rancharia locality, $1.5 \mathrm{~km}$ south of Araripina, the Santana Formation (revised) rests directly on Paleozoic/ Precambrian rocks (Photo 1C). Nearby, in the same quarry, the upper surface of the gypsum layer exhibits a conspicuous paleokarst topography with large sink holes. The unconformity can be traced to this exposure as the surface separating Paleozoic conglomerates from Cretaceous rocks. The rocks from each sequence are essentially parallel and have been tilted (Photo 1C).

THE ARARIPINA FORMATION (NEW NAME) The Araripina Formation is either seen at surface exposures or is present in the subsurface throughout the area (Fig. 7). The upper part, consisting of dark shale and gypsum, is very well developed in the southwestern part of the plateau around the towns of Araripina, Trindade, and Ipubi. Drilling by Sudene in this area, however, showed that the lower limestone and black shale, which do not outcrop on this part of the basin, underlie the gypsum layer and overlie the basement rocks (Fig. 7).

The reason for choosing the town of Araripina for naming the new formation, instead of a town closer to the type section or another geographic locality, is based on the article 13, remark 13, Code of Stratigraphic Nomenclature (ACSN 1973) which states: "Reference localities may be established to supplement the type locality (type locality contains the type section; type area contains the type locality".

Mining activity, very common in this region, provides but also rapidly takes away good exposures leaving behind a scrambled deposit. Thus, naming a type area can be a useful procedure, since several quarries exist and offer good exposures of the formation. The Araripina region is here considered a type area because the town functions as a center from where a number of quarries can be easily reached. 


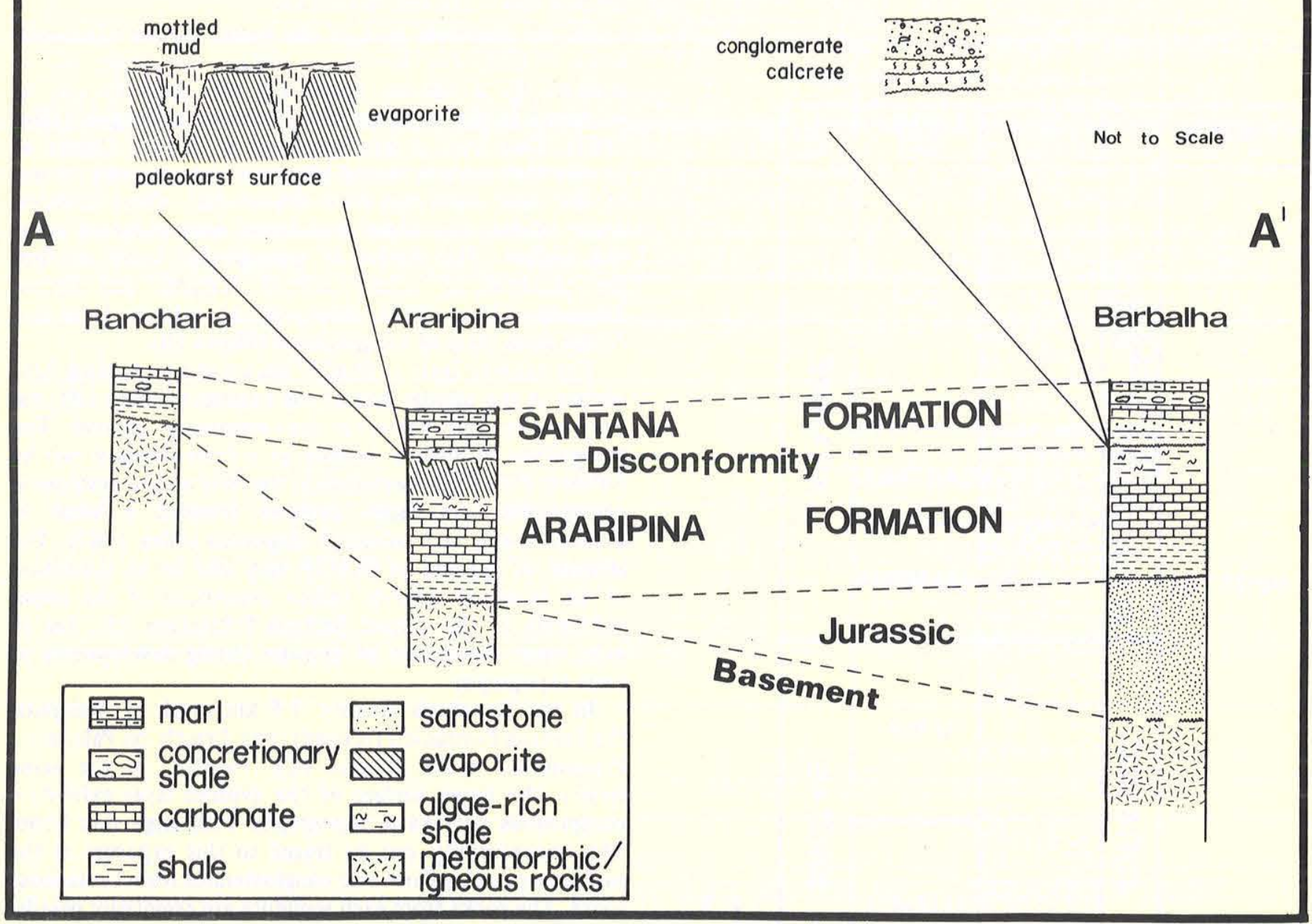

Figure 6 - Diagram illustrating the variable expression of the unconformity surface between the Araripina and Santana Formations across the Araripe Basin. Location of line $\mathbf{A A} \mathbf{A}^{\prime}$ is shown in figure 1. The schematic (not to scale) drawing on the upper part of the figure illustrate the different deposits associated with this disconformity

The type section is the Casa de Pedra Quarry where cores SE-2, -19 , and -22 are located (Fig. 8). The small town of Trindade, the closest to Casa de Pedra, is considered the type locality. In Casa de Pedra, the formation attains a thickness of $70 \mathrm{~m}$ (Fig. 7). Core SE-22 reached gnaisses and schists of the basement, and recovered organic-rich black shale at a position corresponding to the base of the formation overlain by $40 \mathrm{~m}$ of carbonate. A layer of algae-rich laminated shale overlies the carbonate and, in turn, is overlain by a 30 m-thick layer of gypsum and anhydrite.

The kerogen-rich shales recovered by these three cores contain abundant ostracods, gastropods, plant fragments, and algae; in places they are stromatolitic or micritic-pelmicritic. Detrital minerals, such as quartz, feldspar, micas, and heavy minerals are very abundant in the shale. Opaque minerals, mostly nodular or disseminated pyrite specks are also abundant. The limestones are cream, light gray and pink in color, very fine grained and fossiliferous (ostracods, gastropods, and algae). They contain conspicuous, fine-scale, parallel laminae, and small sets of cross laminae (ripple marks, scour and fill).
Petrographically, the limestones exhibit a variety of compositions and textures (see Silva 1983 for more information). Predominantly they are micritic and dolomicritic, ranging to pelmicrite and biomicrite. Diagenetic imprints and stylolites are abundant.

In quarries, the evaporites form white, tabular layers of secondary gypsum exhibiting a variety of crystalline types (alabaster, satin spar, selenite crystals, and rosettes). Petrographically, the evaporites are predominantly secondary gypsum with some relict anhydrite. Diagenesis has extensively modified these evaporites, but core SE-2 still displays textures and varieties of primary anhydrite and gypsum. The study of this core provides additional information for the facies interpretation and environmental reconstruction of the basin during the evaporitic stage and the results are shown in Silva (1983).

THE SANTANA FORMATION (REVISED) The Santana Formation, as revised here, occurs continuously throughout the basin as a conspicuous sequence of alternating layers of concretionary-calcareous shale, limestone, and sandstone (Photo 2). It is unconformably overlain by 
the Exu Sandstone (Albian) and unconformably overlies the Araripina Formation. The Santana Formation locally rests unconformably on algal laminated shale of the Araripina Formation as in IBACIP (Photo 2); it may also overlie the gypsum layer as in Araripina, or it may rest directly upon Paleozoic and Precambrian rocks (as at Rancharia). Its average thickness is about $50 \mathrm{~m}$. This formation reflects continuous deposition of 1 to $2 \mathrm{~m}$-thick layers of calcareous shale and limestone. Towards the northeast side of the basin, an intertonguing layer of white, loosely cemented sandstone occurs (Fig. 6). The shale presents less organic content than those in the Araripina Formation, but is also rich in ostracods and especially in calcareous concretions in which abundant remains of fish and reptiles are found. The carbonates are very fossiliferous micrites and dolomicrites containing ostracods, gastropods, and plant remains.

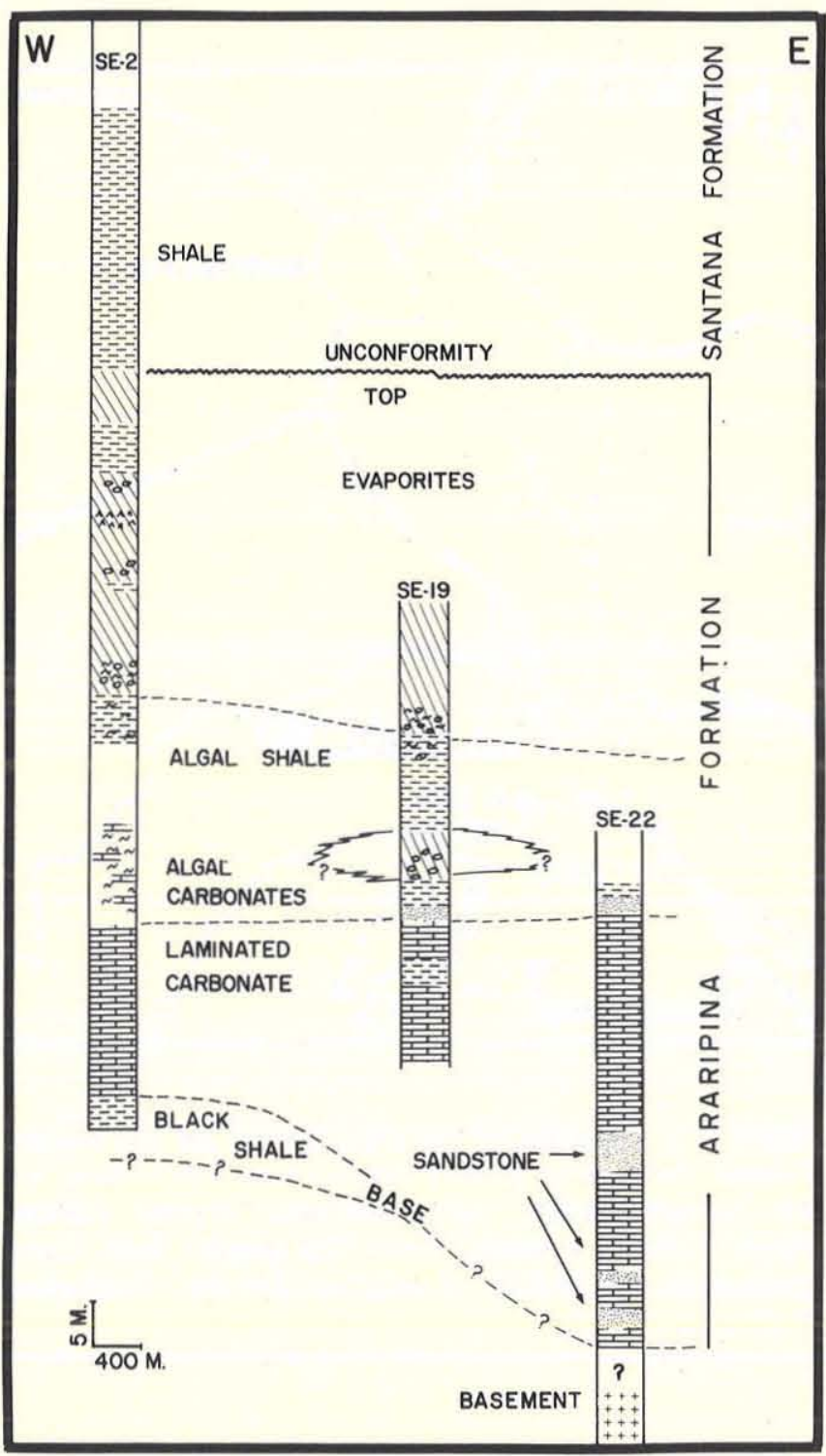

Figure 7 - Type section of the Araripina Formation: cores $S E-2, S E-19$ and $S E-22$ drilled by Sudene in Casa de Pedra Quarry, SW Araripe Plateau (Figure 2 shows location)

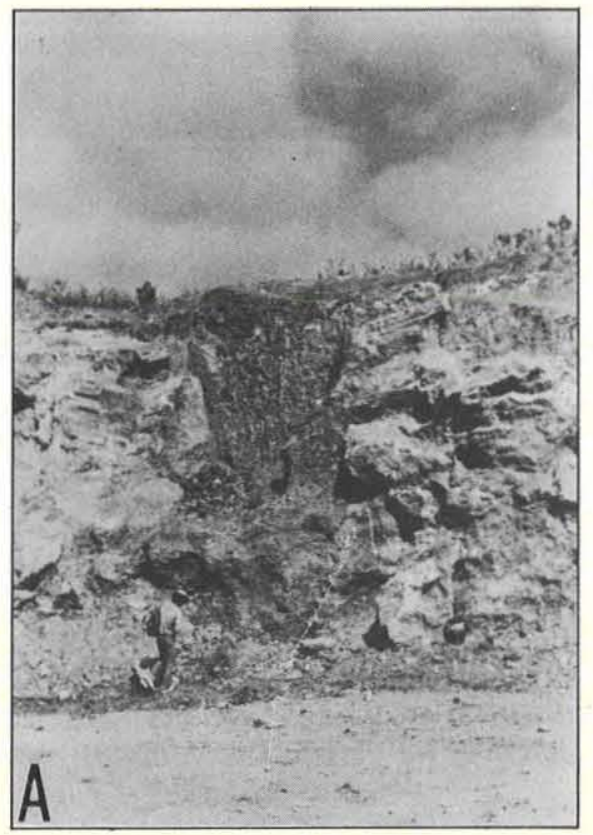

Photo $1 A$ - Dissolution cavity on the top of the grpsum layer. Cavity has been filled by mud. Rancharia Q'uarry on road Araripina-Rancharia, SW of Araripina (figur. ! shows location)

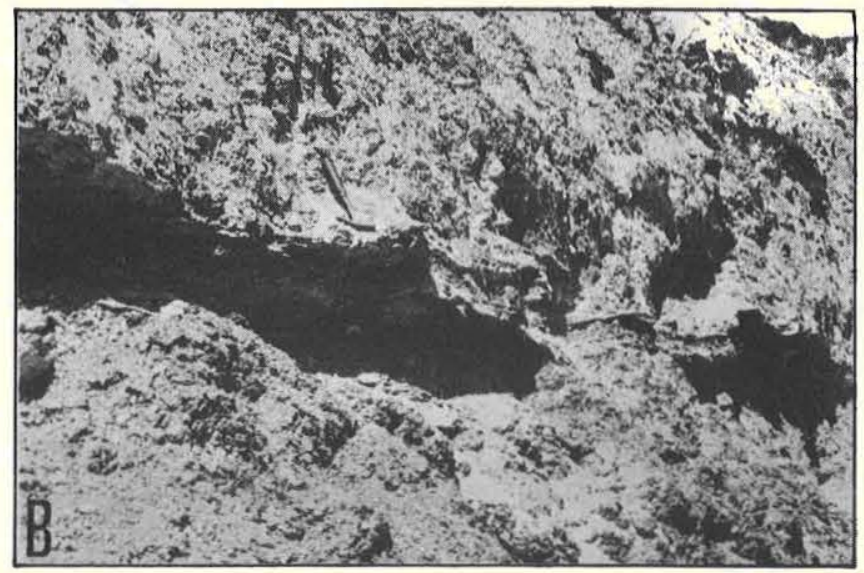

Photo $1 B$ - Calcareous and siliceous laminar crusts forming a calcrete layer, IBACIP Quarry (figure 1 shows location)

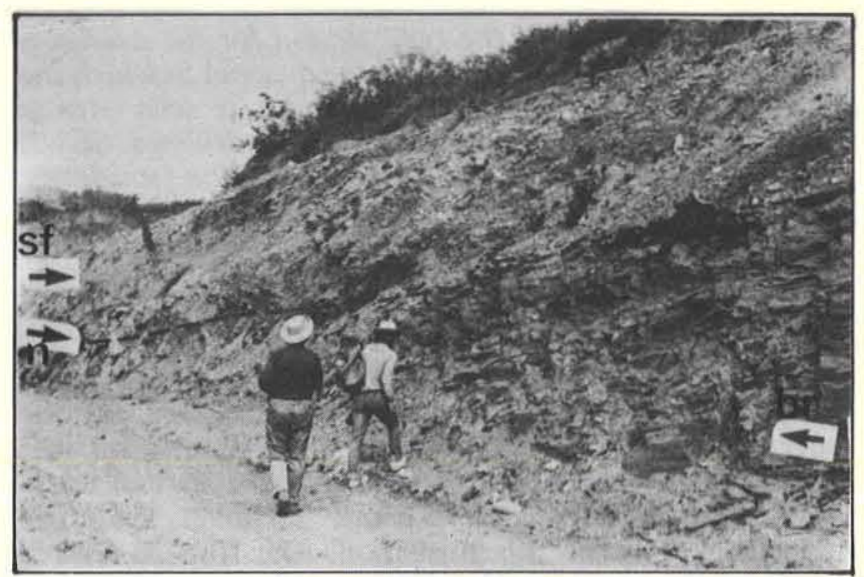

Photo $1 C$ - Santana Formation resting unconformably on Paleozoic/Precambrian rocks. Rancharia Quarry (figure 1 shows location). SF = Santana Formation; $\mathbf{N}=$ Nonconformity; $\mathbf{B R}=$ Basement Rocks 


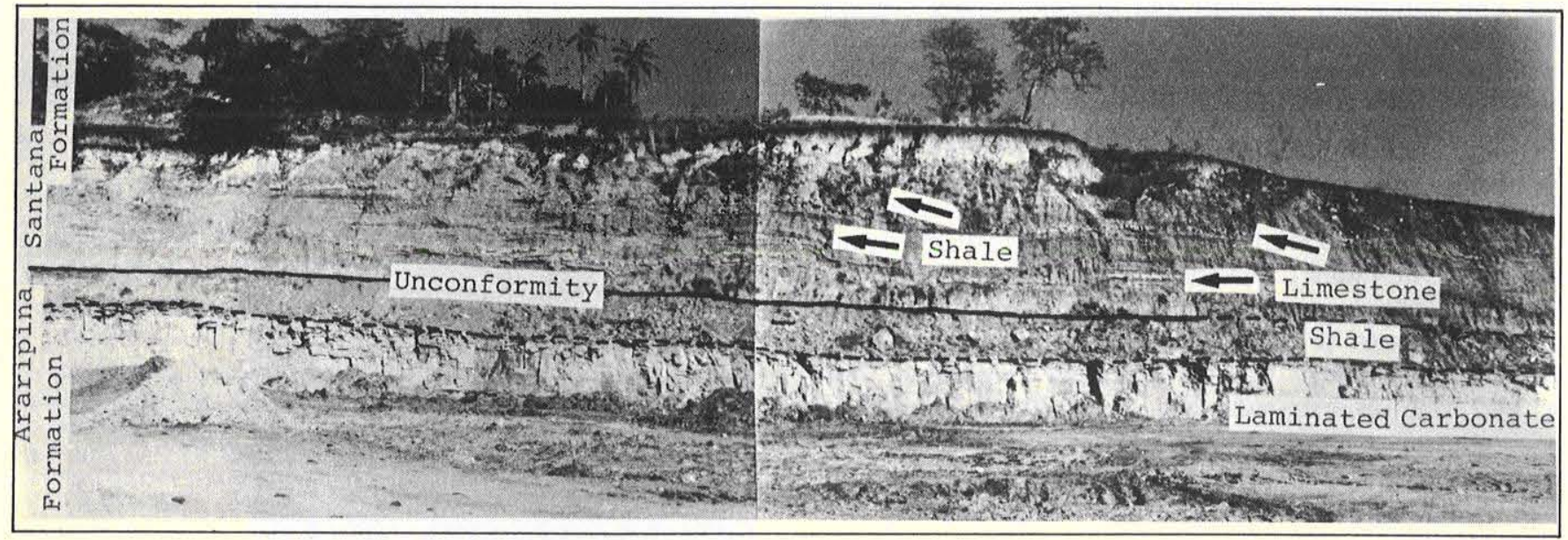

Photo 2 - Type section for the revised Santana Formation: IBACIP Quarry near Vila Caldas, northeast Araripe Plateau (figure 1 shows location). Gypsum layer has been removed by erosion; shales and limestones of the Araripina Formation appear in the basal section of the quarry. Unconformity marked by black line

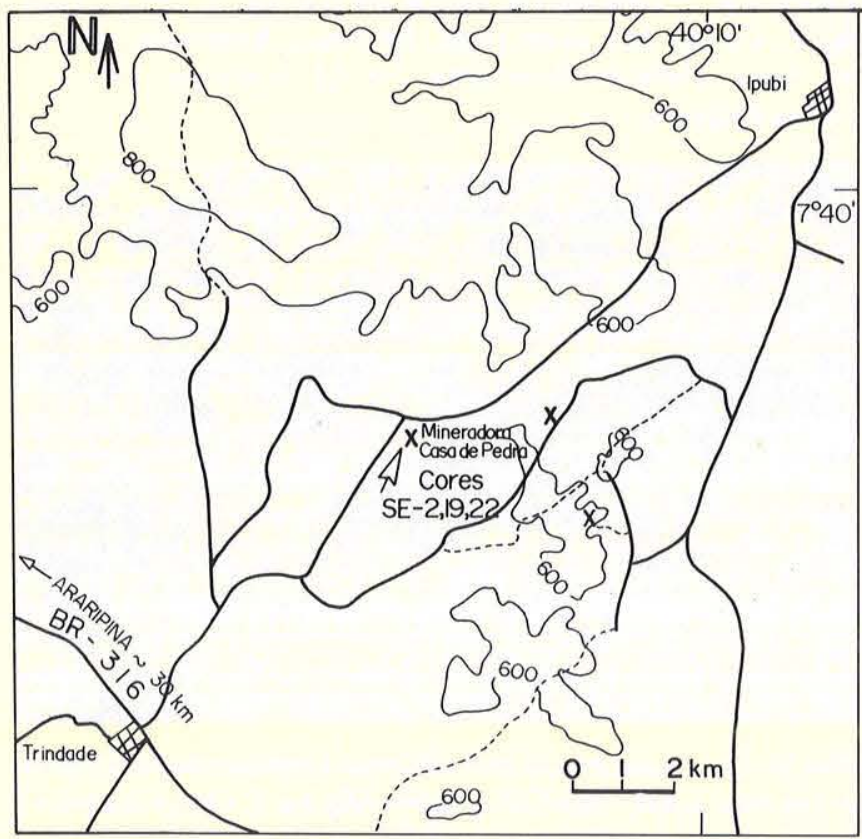

Figure 8 - Location of the type section for the Araripina Formation. Market by crosses are the quarries in which the upper part of the Araripina Formation is seen. Arrow indicates the approximate location of drillings $S E-2$, $S E-19$ and $S E-22$ (Sudene), Araripina region (southwest Araripe Plateau): Quarries located on the Trindade-Ipubi road (figure 1 shows location). From Topographic Map, Quadrangle Ouricuri SB-24-Y-D-IV, 1:1,000,000 by the Serviço Geográfico do Exercito (1969)

Figure 9 shows the locatily here proposed for the neotype section of the revised Santana Formation, the IBACIP Quarry near the town of Barbalha in the northeastern part of the basin, which preserves the most complete section of this formation. The IBACIP Quarry also shows the best example of the underlying conglomerate layer associated with the erosional surface. In this quarry (Photo 2), the upper sequence unconformably rests on top of the shale and limestone of the Araripina Formation. The evaporite layer is not present here.

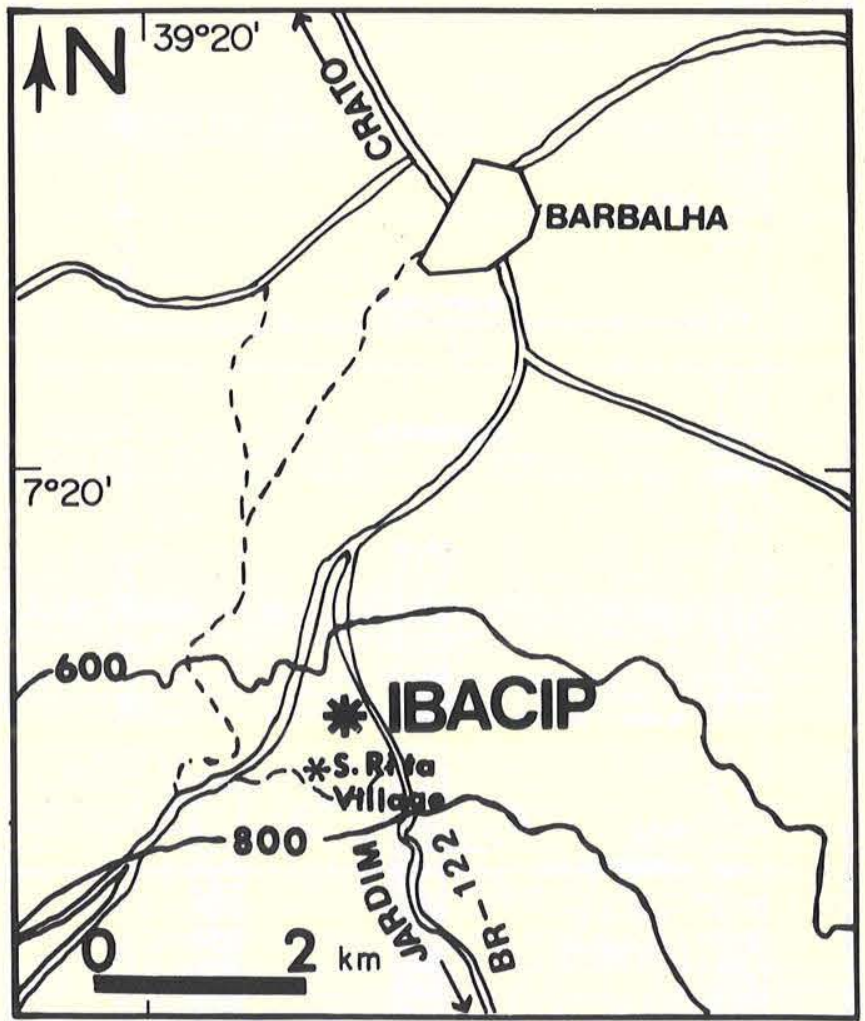

Figure 9 - Location of the type section for the revised Santana Formation: IBACIP Quarry near Vila Caldas, on the Barbalha-Jardim road, northeast Araripe Plateau (figure 1 shows location). From Topographic Map, Crato Quadrangle SB-24-V-II, 1:100,000 Serviço Geográfico do Exército (1969)

The reason for retaining this name is that the name Santana Formation has long been attached to the fossiliferous marl and limestone of the Araripe Plateau (The Sant'Anna Limestone of Small 1913). 
CONCLUSIONS The Lower Cretaceous sedimentary sequence of the Araripe Basin is divided into two formations bounded by unconformites: 1. the lower Araripina Formation (Aptian/Albian), and 2. the upper Santana Formation (revised). A newly detected regional unconformity separates them.

The Araripina Formation lies unconformably on Jurassic strata or nonconformably overlies the Paleozoic and Precambrian basement rocks. This formation includes, in ascending order, black shale, laminated limestone and dolostone, algal-laminated shale, and evaporites (gypsum-anhydrite). The type section for this formation is in Casa de Pedra, southwest of the plateau, near Araripina, a major town in that vicinity. Cores SE-2, SE-19, and SE-22 drilled in Casa de Pedra represent the Araripina Formation. The upper part of the formation which outcrops in the region is seen at Ponta da Serra, São Severino, Alto Bonito, and Lagoa de Dentro Quarries. The Araripina Formation is truncated by a regional disconformity which has variable expression across the basin: a paleokarst surface to the south and a calcrete layer to the north and east.

The upper alternating layers of concretionary-calcareous shale, limestone, and intertonguing sandstone of the Lower
Cretaceous sequence is placed in a revised Santana Formation. The revised Santana Formation lies unconformably between the Exu Formation and the Araripina Formation. The neotype section for the Santana Formation, the IBACIP Quarry located near Vila Caldas, Barbalha, in the northeastern part of the plateau best displays the unconformity separating the two formations.

Lack of recognition of the disconformity separating these two rock formations prevented their stratigraphic relationship from being cleary understood, and consequently the depositional history of these distinct sedimentary sequences have been misinterpreted. The depositional history of the Cretaceous sedimentary rocks in the Araripe Basin is presented by Silva (1983).

Acknowledgements Financial support for this work was provided by the Conselho Nacional de Desenvolvimento Científico e Tecnológico (CNPq) (Proc. 402402/80) and by Dr. J. Sanders. I thank Drs. J. Sanders, L. Gambôa, R. Schweickert, L. Burckle, and J. Damuth for critically reviewing this text. Mrs. Gabriella M. Kerty and Ana Maria Alvarez provided technical assistance, which was very much appreciated. I am grateful to Mrs. Neusa N. da Costa who typed the manuscript.

\section{REFERENCES}

ACSN (AMERICAN COMMISSION ON STRATIGRAPHIC NOMENCLATURE) - 1973 - Code of Stratigraphic Nomenclature. Tulsa, AAPG $22 \mathrm{p}$.

BEURLEN, K. - 1962 - A geologia da Chapada do Araripe. Anais Acad. brasil. Ciênc., 34(3):365-370, Rio de Janeiro.

BEURLEN, K. - 1963 - Geologia e estratigrafia da Chapada do Araripe. In: CONGR. BRAS. GEOL., 17, Recife, 1963, Anais..., Recife, SBG, $47 \mathrm{p}$.

BEURLEN, K. - 1971 - As condições ecológicas e faciológicas da Formação Santana na Chapada do Araripe (Nordeste do Brasil). Anais..., Acad. brasil. Ciênc., 43 (supl.):411-415.

BRAUN, O.P.G. - 1966 - Estratigrafia dos sedimentos da parte interior da Região Nordeste do Brasil (Bacias de Tucano-Jatobá, Mirandiba e Araripe). Rio de Janeiro, DNPM/DGM, 75 p. (Boletim 235).

DNPM - Departamento Nacional da Produção Mineral - 1974a Carta Geológica do Brasil: Folha SB.24 - Jaguaribe.

DNPM - Departamento Nacional da Produção Mineral - 1974b Carta Geológica do Brasil: Folha SC.24 - Aracaju.

DUNBAR, C.O. \& RODGERS, J. - 1975 - Principles of Stratigraphy. New York, J. Wiley \& Sons, 356 p.

JORDAN, D.S. - 1923 - Peixes cretáceos do Ceará e Piauhy. Monographias. Serv. Geol. e Mineral. do Brasil, Rio de Janeiro, v. III, $101 \mathrm{p}$.

KROMMELBEIN, K. - 1965 - Preliminary remarks on some marine Cretaceous ostracods from Northeastern Brazil and West Africa. In: WEST AFRICAN MICROPALEONTOLOGY COLLOQUIUM, 2, Idaban, 1965, Proceedings..., Ibadan, p. $119-123$

KROMMELBEIN, K. - 1965 - On "Gondwana Wealden" ostracoda from NE Brazil and West Africa. In: WEST AFRICAN MICROPALEONTOLOGY COLLOQUIUM, 2, Ibadan, 1965, Proceedings..., Ibadan, p. 113-119.

KROMMELBEIN, K. \& WENGER, R. - 1966 - Sur quelques analogies, remarquades dans les Microfaunes Cretaceous du Gabon et du Brésil Oriental (Bahia et Sergipe). In: REYRE, D. (ed.). Sedimentary Basins of the African Coasts Symposium, New Delhi, 1964, Association of African Geological Surveys, Paris, 1966, 1st Part, Atlantic Coast, p. 193-196.

LIMA, H.R. de - 1979 - Considerações sobre a subdivisão estratigráfica da Formação Santana. Cretáceo do Nordeste do Brasil. Rev. Bras. Geoc., 9(2):116-121.

MABESOONE, J.M. - 1971 - Sediments of the Intracontinental Cretaceous basins in Northeasten Brazil. Estudos Sedimentológicos, Recife, 1(2):33-52.
MABESOONE, J.M. \& TINOCO, I.M. - 1973 - Paleoecology of the Aptian Santana Formation (northeastern Brazil). Paleogeography, Paleoclimatology, Paleoecology, 14:97-118.

MORAES, L. de; VARROS, F.C. de; RAMOS, E. - 1963 - Reconhecimento fotogeológico da Região Nordeste do Brasil, Folha Crato SB.24U, escala 1:250,000, Div. Fom. da Prod. Mineral, DNPM, Rio de Janeiro.

MORAES, J.F.S. de; SANTOS, J. da S.A.; MASCARENHAS, J. de C. - 1976 - Projeto Santana. Relatório Final da Etapa I, Recife, DNPM/CPRM, 269 p. (vol. I).

MORAES, J.F.S. de; SCHEID, C.; SANTOS, J. da S.A. - 1975 Projeto Santana. Relatório Preliminar da Etapa I, Recife, DNPM/CPRM, $104 \mathrm{p}$.

MUNIS, M. de B. - 1971 - Quantificação dos depósitos de gipsito do Araripe (Área Casa de Pedra-Ouricuri, Pernambuco). Superint. do Desenv. do Nordeste, Depart. de Rec. Naturais/ Div. de Geol., Recife, Série Geologia Econômica, 9:45 p.

OLIVEIRA, A.A. de; BRITO, A. de L.F.; SANTOS, M.E.C.M.; CARVALHO, M.S.S. - 1979 - Projeto Chapada do Araripe. Relatório final, Recife, DNPM/CPRM, 123 p. (vol. I).

SCHEID, C.; MUNIS, M. de B.; PAULINO, J. - 1978 - Projeto Santana. Relatório final da Etapa II, Recife, DNPM/CPRM, $136 \mathrm{p}$.

SILVA, M.A. da - 1983 - The Araripe Basin, Northeastern Brazil: Regional Geology and Facies Analysis of a Lower Cretaceous Evaporitic Depositional Complex. New York, 290 p. (Ph.D. Thesis, Columbia University).

SILVA SANTOS, R. da \& VALENÇA, J.G. - 1968 - A Formação Santana e sua paleoictiofauna. Anais Acad. brasil. Ciênc., 40:339-360, Rio de Janeiro.

SMALL, H.L. - 1913 - Geologia e suprimento de água subterrânea no Ceará e parte do Piaui. Publicação Inspetoria Obras Contra Secas, 25 , p. $1-80$

VIANA, C.F. - 1966 - Stratigraphic distribution of ostracoda in the Bahia Supergroup (Brazil). . In: WEST AFRICAN MICROPALEONTOLOGY COLLOQUIUM, 2, Ibadan, 1965, Proceedings..., Ibadan, p. 240-257.

WRIGHT, V.P. - 1982 - The recognition and interpretation of paleokarsts. Two examples from the Lower Carboniferous of South Wales. J. Sed. Petr., 52(1):83-94.

MANUSCRITO

Recebido em 12 de março de 1986 Revisão aceita em 18 de dezembro de 1986 